\section{MAGUNATIP AND WAYANG KULIT: THE INFLUENCE OF MALAYSIAN TRADITIONAL PERFORMING ARTS IN RAZAK ABDUL AZIZ'S 10 PANTUN SETTINGS}

\author{
Mohd Fairuz Zamani \\ Universiti Pendidikan Sultan Idris
}

Corresponding Author fairuzklavier@gmail.com
Razak Abdul Aziz has been writing music since in the 1980's. His work 10 Pantun Settings is among the most frequently performed work since its complete premiere in May 2018. As this is one of the composer's early works, Razak drew his inspirations from the environment he grew up in as his younger self, having some of the songs in this cycle influenced by Malaysian traditional music he had chanced to encounter. From my investigation, of many of these music, he had special fondness towards magunatip dance and wayang kulit, which he had transformed their idioms into musical notation with his compositional style and used as the music materials in two of the songs in his songcycle 10 Pantun Settings. Music excerpts from these songs are used to demonstrate the transformation process mentioned. Investigation on works inspired and influenced by Malaysian traditional music should be expanded to other local composers, in line with the growing interest in researching local works among academics, gaining its rightful place in the world of academia.

Keywords: Razak Abdul Aziz, 10 Pantun Settings, Malaysian Traditional Performing Arts, Influence, Composer. 


\section{INTRODUCTION}

This paper begins its discussion with introducing Razak Abdul Aziz, briefly mentioning about his academic trainings and career as an academic and a composer, before delving into the works that are the centre of this article, where the author will demonstrate the influence of magunatip (a Sabahan's Murut traditional dance) and wayang kulit (a shadow puppet theater, prominent in Kelantan) in his works. The paper will end with conclusion and discussion, leaving the readers to ponder upon the possibility of future studies in academia, focusing on Razak Abdul Aziz and other local composers, who are in dire need to be brought into the limelight.

\section{COMPOSER'S BACKGROUND}

Razak Abdul Aziz is Malaysian contemporary composer, arguably one of the earliest in the nation (Zamani et. al., 2019, p. 76). He received his academic training at Skidmore College in the USA as an undergraduate, and from Columbia University in the United States and University of Edinburgh in the United Kingdom at the Master of Arts and PhD levels, respectively.

As an academic, he served as a lecturer at the Music Department of Institut Teknologi MARA (now known as Universiti Teknologi MARA UiTM) from 1986 to 1993, teaching music theory, composition, and piano courses. Razak then made the decision to tenure at Universiti Sains Malaysia (USM) Pulau Pinang in 1993, responding to an offer by a renown ethnomusicologist, Tan Sooi Beng, at the same time, returning to his hometown to be close to family, before retiring in November 2019 (Zamani et. al., p.77).

As a composer, many of his works have been performed both locally and internationally. Razak Abdul Aziz, a composer from Penang, Malaysia, has been composing music since the 1980s (Hall, 1988, p.30). His compositional creativity utilizes various mediums of instrumentations - solo piano, vocal works, ensemble, piano duo - just to name a few. Among his notable works are 10 Pantun Settings (19811990), The Fisherman (2015), and Etudes for Piano Solo (2002) (Razak Abdul Aziz, personal interview, 5 May 2018).

\section{10 PANTUN SETTINGS}

This work is perhaps the most performed work by the composer. A work that took 10 years to complete (from 1981 to 1990), the texts were taken from Kalong Bunga Buku 1 (1964), a collection of poems compiled and edited by Zainal Abidin Ahmad (known better as Za'ba), though Razak had specifically drawn text by Ahmad Abdullah in his 
Nyanyian Kanak-Kanak (1938), which he found in this collection (Yoshioka, 2018, p. 47). The following table shows the title of each song in this cycle with the instrumentation:

Table 1: Song Title and Instrumentation

\begin{tabular}{|c|c|}
\hline Song title & Instrumentation \\
\hline No. 1 - Buai Adik & one (1) voice and one (1) piano \\
\hline No. 2 - Buat Kuih & one (1) voice and two (2) pianos \\
\hline No. 3 - Mandi-Mandi & $\begin{array}{l}\text { one (1) voice, one (1) piano, and one (1) } \\
\text { violin }\end{array}$ \\
\hline No. 4 - Jangan Tengok Kami & one (1) voice and two (2) pianos \\
\hline No. 5 - Sorok-Sorok & one (1) voice and two (2) pianos \\
\hline No. 6 - Pinjam Dandang & $\begin{array}{l}\text { two (2) voices, two (2) pianos, and SATB } \\
\text { chorus }\end{array}$ \\
\hline No. 7 - Lumba Berkejar & $\begin{array}{l}\text { one (1) voice, two (2) pianos, and SATB } \\
\text { chorus }\end{array}$ \\
\hline No. 8 - Kalau Salah Jangan Malu & SATB chorus and two (2) pianos \\
\hline No. 9 - Lan, Kula Inson, Lan & one (1) voice and two (2) pianos \\
\hline No. $10-B a, B a, C a k !$ & one (1) voice and two (2) pianos \\
\hline
\end{tabular}

This narration of cycle centres around Razak's memories in his earlier days, reminiscing the scenery he had witnessed growing up in Penang in the 1960s and 1970s. During the interview with the composer on 24 November 2018, he deliberately mentioned that two songs from this cycle, No. 4 and 6, were inspired by Sabahan magunatip and Kelantanese wayang kulit, respectively, he chanced to watch in his early years. 


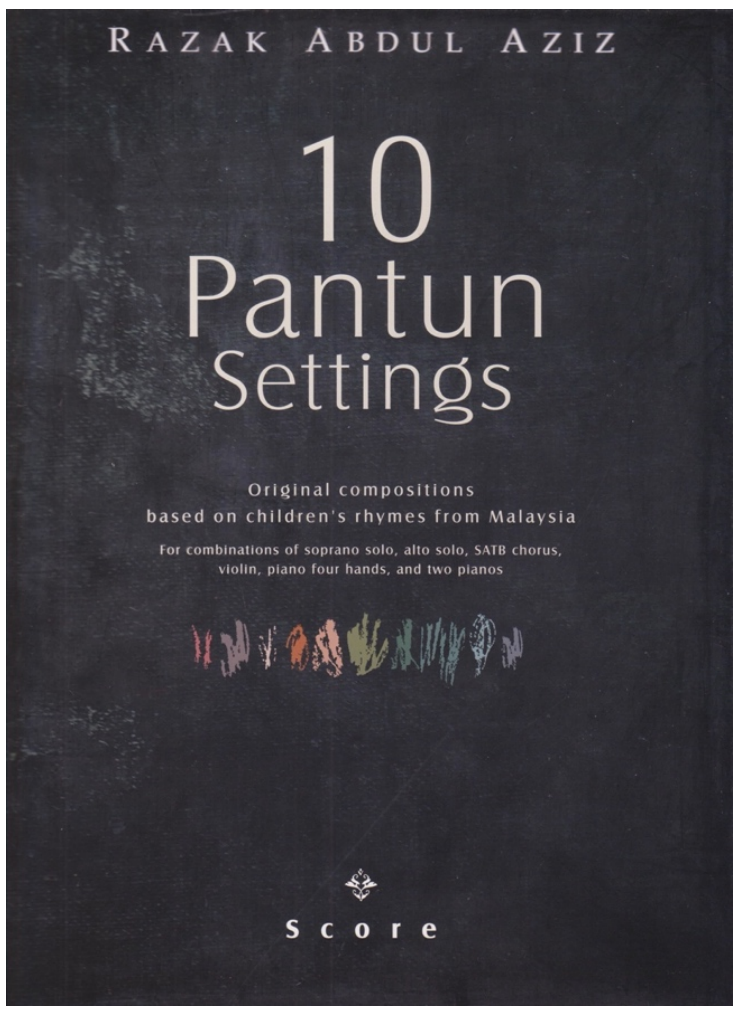

Figure 1: Cover page of 10 Pantun Settings

\subsection{Jangan Tengok Kami}

The fourth song in this cycle, Jangan Tengok Kami (Do Not Look at Us), was written with an interesting imagination. Razak imagined two groups of villagers, where each group was carrying two crossed pairs of bamboo sticks. These two groups coincidentally met at a junction. As none of them wanted to yield, that had made them to break into a duel, challenging each other with their magunatip skills (an art of the Murut people of Sabah). He transformed this imagery into music notation by using two pianos; Piano 1 and Piano 2, mimicking the percussive bamboo sound that accompanied the dance by using loud dynamics and accents. The composer also used various harmonic procedures (e.g.: quartile harmony, descending 2 nds, tritone, upper tertian chords), to enhance the percussive quality on the pianos (Razak Abdul Aziz, personal interview, 24 November 2018). 


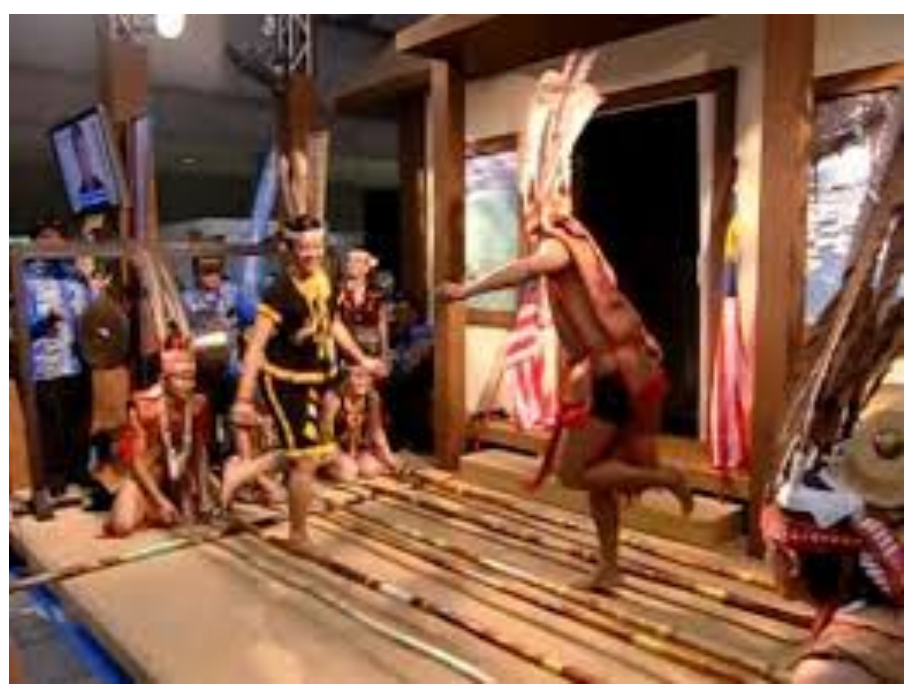

Figure 2: Magunatip dance of Murut people of Sabah

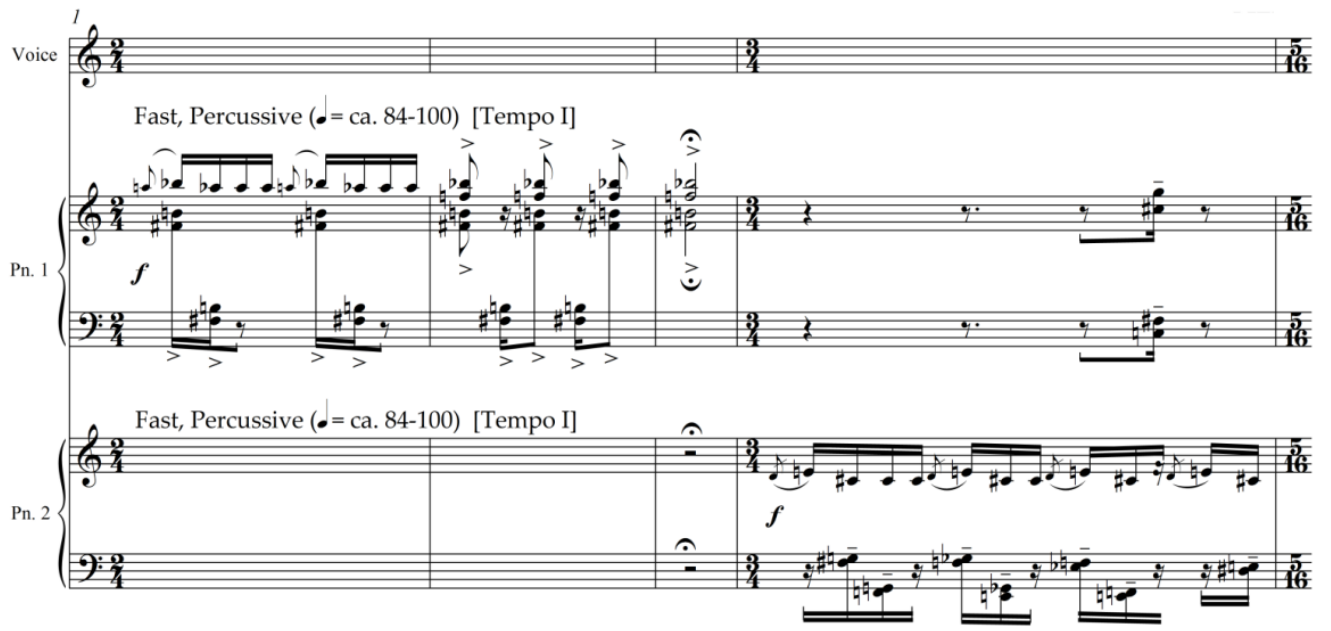

Figure 3. Excerpt from the opening bars of Jangan Tengok Kami

Razak did not intend to incorporate the rhythmic pattern of magunatip in this song as he only took the percussive idea of the rhythm and reimagined it using his interpretation through the use of loud dynamics and accented rhythmic patterns, together with the harmonic procedures mentioned earlier, which could be observed in the excerpt above.

\subsection{Pinjam Dandang}

Pinjam Dandang is the only song in this cycle that utilizes two solo singers; one soloist sings the character of a young girl who is playing a make-believe game, and the other singer plays the character of an elderly woman (Mak Uda), alongside two pianos, an SATB choir, and a percussion ensemble. Razak Abdul Aziz was inspired by a traditional 
shadow puppet theatre that is popular in Kelantan, wayang kulit, when composing this song (Razak Abdul Aziz, personal interview, 24 November 2018).

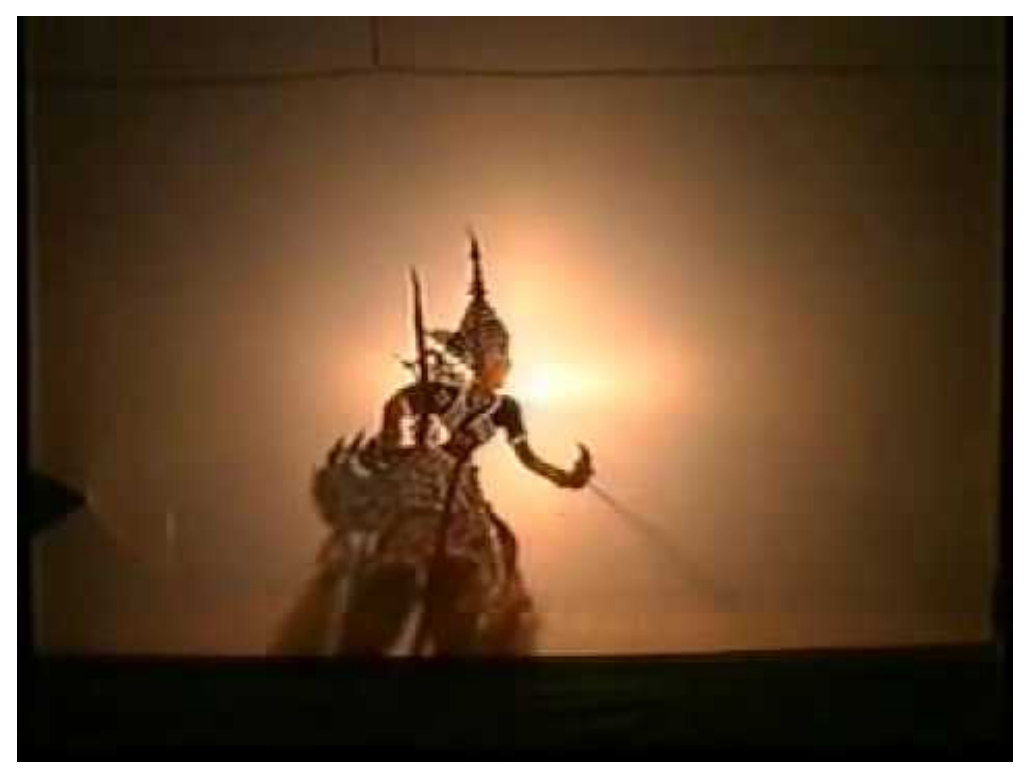

Figure 4: Kelantanese Wayang Kulit

Generally, in a shadow theatre play, the story would centre the royalties and fairy tales. Hence, the opening act begins with an overture Bertabuh - a regal instrumental piece, played by the wayang kulit music ensemble, led by the serunai (shawm) (Matusky, 1997, p. 19). Razak incorporated the idea into this song, giving the introduction a majestic opening played by the two pianos to imitate the regality of Bertabuh, setting the ambience right, imagining curtain rising at the beginning of this piece.

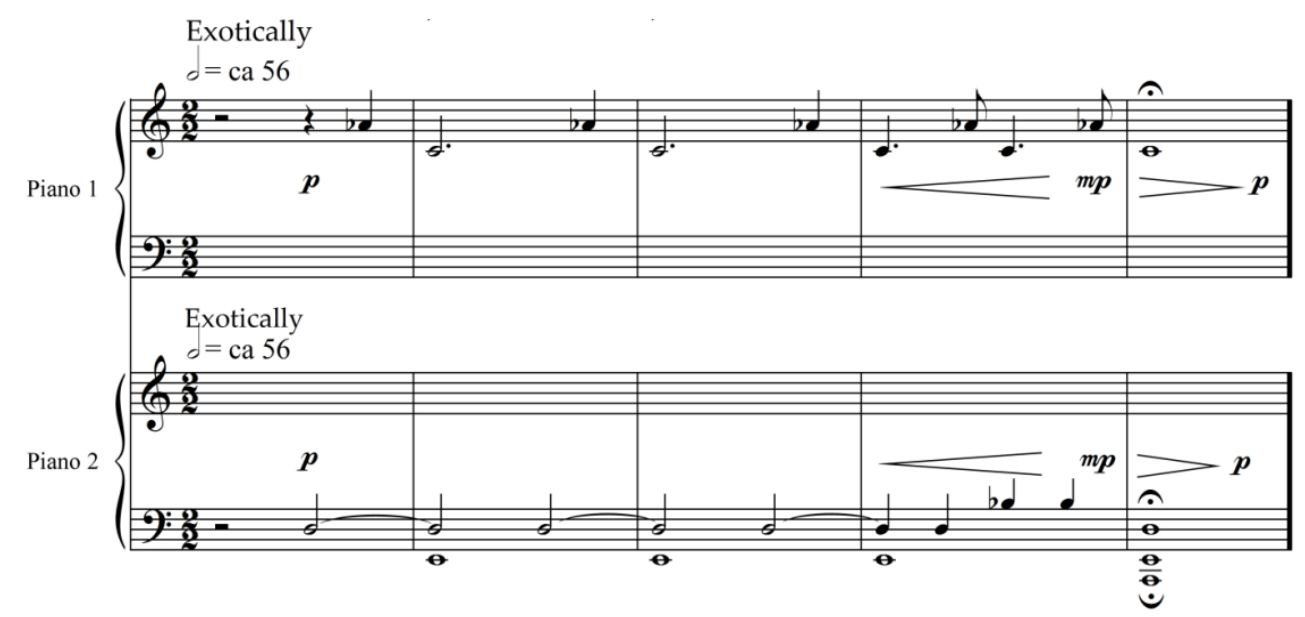

Figure 5: Soft and Majestic Opening of Pinjam Dandang, Mimicking the Overture of Wayang Kulit 
This material will recur later in the middle and at the end as a tool to tie and conclude the song, respectively.

Razak Abdul Aziz demands Sprechstimme (a singing style first introduced in the music literature by Arnold Schoenberg in the early $20^{\text {th }}$ century) from the soloists for certain parts in this song. This is written by using a cross " $x$ " symbol on the music stem. The singers need to sing the written pitch 'half spoken, half sung' (colloquial and without vibrato) to imitate the characters in wayang kulit play, which are spoken. Often times in this song, this singing style occurs when the main characters (the young girl and Mak Uda) are having conversation with each other. The excerpt below shows an example of this conversation.

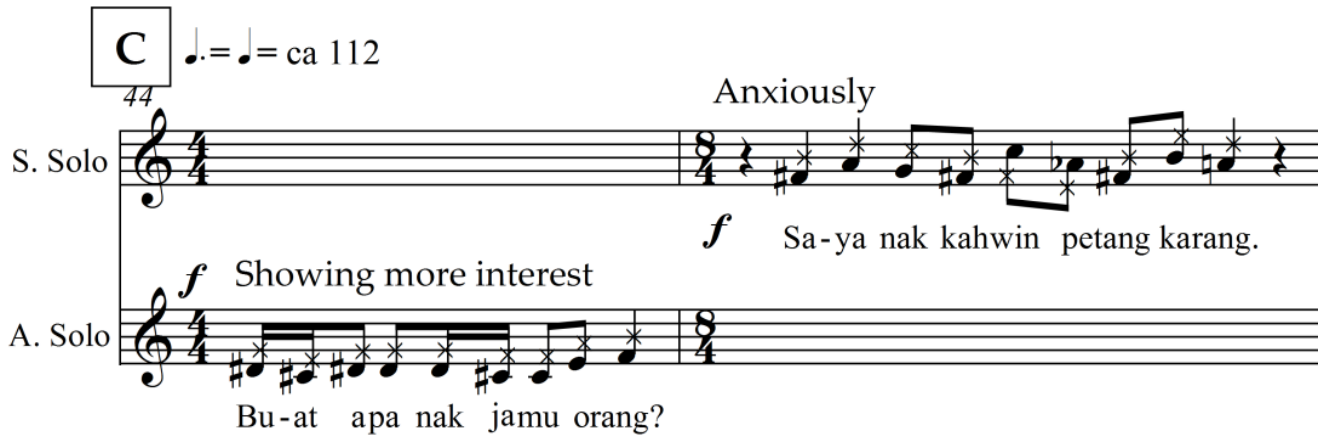

Figure 6. Sprechstimme Duo Vocal Line

The soloists carry out their usual way of singing when the symbols are non-visible from their score. This alternation between Sprechstimme and normal singing is perhaps, to imitate how the characters in wayang kulit interact with each other, which is in line with Matusky's findings on Dalang Muda's role:

'...fixed spoken narration, dialogue, and stereotyped voices for specific charactertypes... begin to sing specific pieces...'(p.21).

\section{CONCLUSION AND DISCUSSION}

Malaysian traditional performing arts have always been a source of inspiration for composers. As seen in two (2) songs in 10 Pantun Settings, Razak Abdul Aziz took the idioms of magunatip and wayang kulit and translated them into music using his own imagination and interpretation, alongside the chosen text from Ahmad Abdullah's Nyanyian Kanak-Kanak. Having these songs with such inspiration works well with other songs in the cycle as the complete narration takes places in a Malay village setting in the 1960's, as staged during its premiere in May 2018 (Nico0120, 2018). 
Many other local composers were inspired by Malaysian traditional music. Amongst are Tazul Izan Tajuddin, Marzelan Salleh, and Ramlan Imam (just to name a few). Tazul's music were also influenced by the Malaysian traditional music as seen in his work the opera Puteri Saadong (2013-2016). Tazul incorporates gamelan and mak yong ensembles in the composition, alongside standard Western orchestral instruments (string, woodwind, brass, and percussion) in its orchestration. During its premiere in January 2015, Tunku Abidin Muhriz reviewed this work in The Borneo Post, saying, "[a]t times the spiritual meanderings of the rebab are incised by a pianissimo discord from the first violins, at others the oboe is employed to imitate a serunai" (30 January 2015).

Marzelan Salleh, in his piano solo work Puteri Gunung Ledang (2015), was mesmerized by the tale of a mythological princess, Puteri Gunung Ledang, who allegedly lived during the late era of Melaka Sultanate. She fell in love with Hang Tuah, a Malay warrior who was assigned by the sultan to propose to the princess on his behalf, only to end with a tragedy. In Marzelan's mind, he uses two (2) types of scales that are synonym to gamelan music, the slendro and pelog, which could be found in Malay gamelan of Malaysia (though the ensemble originated from Indonesia) to portray the two (2) characters, Puteri Gunung Ledang and Hang Tuah (Salleh, 2018, p.12).

Ramlan Imam, in his art song Putera for voice and piano, included an interlude and a postlude written in Malay dance joget rhythmic pattern. This song was originally part of a musical theater Merdeka (2001), where Ramlan was assigned to write an orchestral music for this play (libretto by Hatta Azad Khan). Over time, he felt this song could be further explored to stand alone as an art song, hence, rewriting the music for solo voice and piano (Imam, 10 March 2020).

This discussion opens up a few possibilities for future investigations; first on Malaysian composers such as Razak Abdul Aziz and others, second on the works of these composers, how they are inspired by their cultural surroundings, childhood exposure, and adulthood experiences While a handful of music academics are fascinated with research on Western music, there is a heightened interest amongst local researchers who are starting pay attention on our homegrown composers. It is vital to have local academics researching on our composers and their works, be it inspired by Malaysian traditional performing arts or other sources, as it is time to take these composers to a higher platform, standing tall together with their Western counterpart. 


\section{REFERENCES}

1. Aziz, R. A. (2018, 5 May). Existing and upcoming works [Personal interview].

2. (2018, 24 November). Compositional style [Personal interview].

3. Hall, V. (1988, November 27). Razak Abdul Aziz the reluctant composer. The Star.

4. Imam, R. M. (2020, 10 March). On Putera and Merdeka [Whatsapp interview].

5. Nico0121. (2018, May 17). ASWARA OPERA 2018 - Part1: "10 Pantun Settings" 1st night (Full Length). Retrieved from https://www.youtube.com/watch?v=eexBc73fscwandt=1526s

6. Matusky, P. (1997). Malaysian shadow play and music: continuity of an oral tradition. Penang: Asian Centre.

7. Muhriz, T. A. (2015, January 30). A ground-breaking cultural ornament. Borneo Post Online. Retrieved from https://www.theborneopost.com/2015/01/30/aground-breaking-cultural-ornament/

8. Salleh, M. (2018). Regional Pride in Music Composition. Malaysian Journal Of Performing And Visual Arts, 4(1), 7-17.

9. Tazul Izan Tajuddin - Composer. (n.d.). Retrieved March 10, 2020, from http://www.tazultajuddin.com/

10. Yoshioka, Y. (2018). Razak Abdul Aziz's 10 Pantun Settings. International Music and Performing Arts Conference (Abstract), 47.

11. Zamani, M. F., Idrus, M. M., and Goh, Y.L. (2019). Razak Abdul Aziz: The Forgotten Composer. ASEAN Journal of Management and Business Studies, 1(1), 76-83. 